\title{
JAN SOBIESKI W OCZACH CUDZOZIEMSKICH PAMIĘTNIKARZY
}

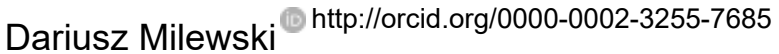

Uniwersytet Kardynała Stefana Wyszyńskiego w Warszawie

\section{ABSTRACT \\ JOHN SOBIESKI IN THE EYES OF FOREIGN DIARISTS}

The topic of this article is the way king John III Sobieski was presented by some foreign diarists in selected aspects: origin and education, interests in philosophy, command and military glory, participation in the Holy League, election and avarice, description and overall assessment.

Keywords: John Sobieski, diarists.

Słowa kluczowe: Jan Sobieski, pamiętnikarze.

Osoba i działalność Jana III Sobieskiego stały się przedmiotem zainteresowania współczesnych mu cudzoziemców, którzy częstokroć zapisywali swoje wrażenia $\mathrm{w}$ formie relacji z podróży bądź pamiętników. Zainteresowanie królem polskim było podsycane zarówno przez pewną egzotykę Rzeczypospolitej i jej ustroju - czego beneficjentem był sam Sobieski, zostawszy królem mimo niepochodzenia z monarszej rodziny - jak i słynne na całą Europę zwycięstwo wiedeńskie w 1683 roku. Jak wiadomo, nie tylko pokrzyżowało ono zaborcze plany tureckie, ale i „wybawicielskie" zamysły Króla Słońce, Ludwika XIV, który po spodziewanym upadku Wiednia stałby się jedynym monarchą zdolnym ocalić Rzeszę przed zalewem osmańskim ${ }^{1}$.

Analiza relacji cudzoziemskich przynosi zwykle dobre rezultaty, choć obarczona jest nieuchronnym marginesem błędu, związanym z nieznajomością przez autorów wszystkich aspektów opisywanej przez nich rzeczywistości. Niemniej potrafią oni dostrzec sprawy „zwyczajne” dla autochtonów, które umykają ich uwadze. Przystępując do zagadnienia wizerunku Jana III w oczach cudzoziemców, skupimy się na

1 Zob. J.A. Lynn, Wojny Ludwika XIV 1667-1714, tłum. W. Brillowski, Oświęcim 2015, s. 159-160. 
tym, jak ów pogromca Turków, będący w swej ojczyźnie obiektem bezpardonowej krytyki ze strony opozycji, był postrzegany przez zdecydowanie mniej zaangażowanych w polskie spory polityczne obcokrajowców ${ }^{2}$. Zdając sobie sprawę z dużej liczby zachowanych wspomnień cudzoziemców dotyczących Jana III Sobieskiego, zmuszeni jesteśmy dokonywać wyboru. Dotyczy on zarówno samych utworów, jak i zawartych w nich treści.

Na potrzeby niniejszego artykułu zdecydowaliśmy się wybrać dzieła następujących pamiętnikarzy: Irlandczyka Bernarda O'Connora ${ }^{3}$, Włocha Giovanniego Fagiuoli $^{4}$ oraz Francuzów: Philippe'a (Filipa) Duponta ${ }^{5}$, M. de Mongrillona ${ }^{6}$ i Gasparda de Tende ${ }^{7}$.

Ponieważ będący przedmiotem naszej analizy autorzy, jak i ich dzieła są znani polskiej literaturze przedmiotu, przywołamy w tym miejscu jedynie najważniejsze informacje. Otóż Bernard O'Connor (1665/1666-1698) przebywał w Polsce krótko w latach 1694-1695. Sławę zdobył, prawidłowo diagnozując śmiertelną chorobę siostry króla, Katarzyny z Sobieskich Radziwiłłowej, co zapewniło mu - skądinąd niezbyt pożądany - awans na nadwornego lekarza królewskiego ${ }^{8}$. Wyjechawszy z Polski w styczniu 1695 roku z Teresą Kunegundą Sobieską do Bawarii, powrócił stamtąd na Wyspy Brytyjskie. Tamże w 1698 roku wydał swe dzieło The History of Poland in Several Letters to Persons of Quality, odpowiadając na wzrost zainteresowania opinii publicznej sprawami Polski po śmierci Jana III Sobieskiego?.

2 Na temat walk Jana III z opozycją w okresie powiedeńskim zob. A. Czarniecka, ,, Nikt nie stucha mnie za życia...". Jan III Sobieski w walce z opozycyjna propaganda (1684-1696), Warszawa 2009.

3 B. O'Connor, Historia Polski, tłum. W. Duży, T. Falkowski, P. Hanczewski, K. Pękacka-Falkowska, red. nauk. P. Hanczewski, Warszawa 2012. Uwagi o Janie III zawiera tom I, list IV - Do czcigodnego Williama, hrabiego Yarmouth: O rodzinie i nadzwyczajnych czynach Jana III, króla Polski, jak również o matżeństwie jego córki z obecnym elektorem Bawarii, s. 178-221.

4 G.B. Fagiuoli, Memorie e ricordi di quello che accadrà alla giornata di me Giovan Battista Fagiuoli 1672 ab incarnatione dell'età mia d'anni XII fino al 1695, thum. części dot. Polski: J.Ch. Fagiuoli, Djariusz podróży do Polski wyjęty z pamiętników Jana Chrzciciela Faggiuoli, wyd. W. Kulczy cki, „Czas. Dodatek miesięczny” 1858, R. 3, t. 11, s. 237-306; omówienie A. Sajk ow ski, W stronę Wiednia. Dole i niedole wojenne w świetle listów i pamiętników, Poznań 1984, s. 292-313. Najnowsze wydanie: G.B. Fagiuoli, Diariusz podróży do Polski (1690-1691), oprac. M.E. Trzeciak, Warszawa 2017.

5 Ph. Dupont, Pamiętniki historyi życia i czynów Jana III Sobieskiego, tłum. B. Spieralska, oprac. D. Milewski, Warszawa 2011. Omówienie: D. Milewski, „Pamiętniki...” Philippe'a Duponta, czyli historia zwycięstw i stawy Jana Sobieskiego [w:] Z dziejów staropolskiego pamiętnikarstwa. Przekroje i zbliżenia, red. P. Borek, Kraków 2012, s. 251-267.

6 M. de Mongrillon, Pamiętnik, oprac. Ł. Częścik, Wrocław 1982.

7 G. de Tende, Relacja historyczna o Polsce, thum. i red. nauk. T. Falkowski, wprowadzenie M. Forycki, Warszawa 2013.

8 B. O'Connor, op. cit., s. 213-214; J. Pietrzak, Księżna dobrodziejka Katarzyna z Sobieskich Radziwitlowa (1634-1694), Warszawa 2016, s. 475-477.

9 B. O'Connor, op. cit., s. 11-25. Zob. też: S. Szpilczyński, Z. Wójcik, O’Connor Bernard (ok. 1666-1698) [w:] Polski słownik biograficzny [dalej: PSB], t. XXIII, Wrocław-Warszawa-KrakówGdańsk 1978, s. 517-520; Z. Wójcik, Polska w oczach irlandzkiego lekarza-humanisty Bernarda Connora [w:] Biedni i bogaci. Studia z dziejów spoteczeństwa i kultury ofiarowane Bronisławowi Geremkowi w sześćdziesiąta rocznicę urodzin, red. M. Aymard i in., Warszawa 1992, s. 385-393. 
Florentyńczyk Giovanni Battista Fagiuoli (1660-1742), „znany ze złośliwego języka", jak wyraził się o nim Alojzy Sajkowski ${ }^{10}$, pojawił się w Polsce w czerwcu 1690 roku w orszaku nowo przybywającego nuncjusza Andrei Santa Crocego jako jego sekretarz. 9 lipca uczestniczył w audiencji u króla, co dało mu sposobność osobistego poznania monarchy. Swoje uwagi spisywał w konwencji porównywania warunków włoskich z polskimi (utyskiwał m.in. na słabą znajomość języka włoskiego wśród Polaków), przy czym nie szczędził Sarmatom drobnych prztyczków. Jego wspomnienia (Memorie e ricordi...) obejmują trzy tomy: 1 (1672-1695), 2 (16961704) i 3 (po 1704), z których polskiemu czytelnikowi udostępniono wybraną część na łamach krakowskiego „Czasu” w 1858 roku $^{11}$. Najnowsze, krytyczne wydanie tej części pamiętników obejmuje też nieco dłuższy okres, od samego wyjazdu z Florencji do powrotu tamże (5 kwietnia 1690 - 16 lipca 1691). W dalszej części tekstu będziemy odwoływać się właśnie do tego wydania.

Dupont - a właściwie Philippe la Masson (ok. 1650 - po 1725) - to bodaj największy wśród francuskich pamiętnikarzy admirator króla Jana III. Znał go też bardzo dobrze, służąc jako inżynier wojskowy w armii polskiej od początku lat siedemdziesiątych XVII wieku, a z czasem stając się zaufanym dworzaninem Jana III i Marii Kazimiery. Swoje wspomnienia spisał we Francji, pod koniec życia, a doczekały się druku w oryginale za sprawą Ignacego Janickiego dopiero w 1885 roku w Warszawie, dwa lata po opublikowaniu polskiego thumaczenia pamiętników Dalairaca ${ }^{12}$. Pisząc o Janie III, akcentował jego dokonania wojenne i na wszelki możliwy sposób bronił dobrego imienia monarchy ${ }^{13}$.

Nieznany z imienia de Mongrillon przebywał w Polsce w latach 1693-1697 jako kurier i człowiek do zadań specjalnych w ambasadzie Melchiora de Poligniaca. Dzięki swym powiązaniom z francuskim dyplomatą miał okazję obserwować z bliska rodzinę i dwór królewski. Na bieżąco też spisywał swoje wrażenia, tworząc pamiętnik, będący w istocie rzeczy zbiorem portretów poszczególnych osób. Po raz pierwszy ukazał się drukiem w Amsterdamie w 1759 roku jako Mémoires et anecdotes pour servir à l'histoire de la Pologne contenant l'abrégé de la vie de la reine Louise Marii $[s]$ de Gonzague... Portrait du roi Jean Sobieski et l'histoire de la concurrence du prince de Conti et de l'électeur de Saxe, pour la couronne de Pologne w pierwszym tomie Curiosités historiques ou recueil de pièces utiles à l'histoire de France et qui n'ont jamais paru'14.

10 A. Sajkowski, W stronę Wiednia ..., s. 300.

11 Zob. przypis 4 i A. Sajkow ski, W stronę Wiednia ..., s. 292-295.

12 Mémoires pour servir à l'histoire de la vie et des actions de Jean Sobieski III, du nom roi de Pologne par Philippe Dupont attaché à ce prince en qualité d'ingénieur en chef de l'artillerie, publiés d'après manuscrit par I. Janicki, Varsovie 1885 (Pamiętniki do historii życia i czynów Jana III Sobieskiego, króla polskiego przez Filipa Duponta petniacego przy królu obowiązi głównego inżyniera artylleryi, wydał z rękopisu I. Janicki, Warszawa 1885).

13 Na temat Duponta i okoliczności powstania jego dzieła zob.: K. Piwarski, Dupont Filip, PSB, t. VI, Kraków 1948, s. 6-7; M. Komaszyń ski, Filip Dupont - dworzanin doskonaty [w:] Studia z dziejów epoki Jana III Sobieskiego, red. K. Matwijowski, Wrocław 1984, s. 197-209; D. Milewski, op. cit., s. 254-257.

14 M. de Mongrillon, op. cit., s. 18-25. 
Gaspard de Tende (1618-1697), starannie wykształcony i świetnie znający łacinę, przebywał w Polsce długo i w dwóch odstępach czasu - najpierw na dworze Ludwiki Marii, by po jej śmierci i abdykacji Jana Kazimierza wrócić do Francji. Przyjechał znów nad Wisłę w 1674 roku jako sekretarz posła francuskiego Toussainta de Forbin-Jansona i po elekcji Jana Sobieskiego pozostał w Rzeczypospolitej aż do śmierci króla. Poznał dobrze zarówno kraj, jak i rodzinę Sobieskich i jeszcze za życia opublikował we Francji opis Rzeczypospolitej - choć uczynił to pod pseudonimem rzekomo nieżyjącego już wówczas pana de Hauteville ${ }^{15}$. Dzieło to szybko zdobyło sobie popularność, w znacznym stopniu wpływając na wizerunek Polski u poddanych Ludwika XIV, utrwalając różne stereotypy, ale i dając solidną porcję wiedzy ${ }^{16}$.

Jako kryteria oceny króla przyjęto:

- pochodzenie i wykształcenie;

- Sobieski jako filozof;

- Sobieski jako wódz i jego sława wojenna;

- Liga Święta;

- elekcja i skąpstwo króla;

- rysopis;

- ogólna ocena króla.

Zdajemy sobie sprawę, że nie możemy w krótkim studium wyczerpać tematu, jak też nie uzyskamy całościowego obrazu Jana III, jaki zachował się na kartach pamiętników obcokrajowców. Niemniej przyjęte kryteria pozwolą na uchwycenie pewnych szczególnych cech, jakimi cudzoziemcy charakteryzowali „Lwa Lechistanu”. Przy okazji dowiemy się też, kogo spośród wymienianych pamiętnikarzy interesowały poszczególne elementy z biografii polskiego króla.

\section{JAN SOBIESKI - POCHODZENIE I WYKSZTAŁCENIE}

$\mathrm{Na}$ temat pochodzenia i wykształcenia króla znajdujemy ciekawe informacje u O'Connora. Zaznaczył on, iż rodzina Sobieskich jest starożytna i szlachetna, choć nie najznakomitsza ani najbogatsza ${ }^{17}$. Oceniając edukację monarchy, pisał, że jest on starannie wykształcony, a w podróżach poznał to, co powinien. Pamiętnikarz przypomina, że Sobieski był we Francji, Anglii, Niemczech i Włoszech, uzyskując na koniec awanse wojskowe za Jana Kazimierza ${ }^{18}$. Gdzie indziej O'Connor podsumował tę część biografii królewskiej następująco: „Król był elokwentny, bardzo otwar-

15 Le Sieur de Hauteville, Relation historique de la Pologne contenant le pouvoir de ses Rois, leur élection, \& leur Couronnement, les privileges de la Noblesse, la Religion, la Justice, les moeurs \& les inclinations des Polonois; avec plusieurs actions remarquables, Paris 1686.

16 M. Forycki, Gaspard de Tende i jego „Relation historique de Pologne” [w:] G. de Tende, op. cit., s. 11-17; K. Targosz, Uczony dwór Ludwiki Marii Gonzagi (1646-1667). Z dziejów polsko-francuskich stosunków naukowych, Warszawa 2015, s. 120-121, 203.

17 B. O'Connor, op. cit., s. 184.

18 Ibidem, s. 185. 
ty i niezwykle uprzejmy. Posiadał większość zalet niezbędnych szlachcicowi. Był nie tylko biegły w sprawach wojskowych, ale też dobrze zorientowany w kulturze i nauce. Oprócz własnego, języka słowiańskiego, znał: łacinę, francuski, włoski, niemiecki i turecki. Lubował się w historii naturalnej i we wszystkich dziedzinach medycyny. Zdarzyło się, że udzielił nagany duchowieństwu za niewłączenie filozofii nowożytnej do programu nauczania na uniwersytecie i w szkołach"19.

Krócej, ale równie pochlebnie na temat wykształcenia króla wypowiadał się Giovanni Fagiuoli. Zwrócił on uwagę na ogrom wiadomości, jakie ma król, i jego zdolności geograficzne oraz lingwistyczne. Włoch chwalił doskonałą znajomość francuskiego, łaciny i tatarskiego, ciesząc się również, iż król mówi trochę po włosku - choć zdaniem pamiętnikarza była to raczej bierna znajomość tego języka ${ }^{20}$.

\section{JAN SOBIESKI JAKO FILOZOF}

Z wykształceniem króla łączy się ściśle kolejna wyróżniająca go cecha, a mianowicie zamiłowanie do nauki i dysput. Ten rys w charakterze króla został dostrzeżony przez wielu pamiętnikarzy. Dotyczy to także inżyniera wojskowego Philippe'a Duponta, którego zwykle interesowały sprawy wojskowe. Niemniej i on zanotował, że Jan III lubił dyskusje na tematy, które sam poddawał, i czasem udawał, że jest odmiennego zdania, by ożywić dyskusję i doprowadzać uczonych do pasji, co go bawiło ${ }^{21}$. Mocno podkreślał też zalety króla jako rozmówcy: „Rozmowa z królem była zawsze przyjemna i użyteczna. Ci, którzy mieli okazję z nim konwersować, nie czuli się nigdy skrępowani ani zażenowani szacunkiem, jakim otaczano jego osobę, gdyż sam król łagodził to wrażenie, spoufalając się z ludźmi dzięki swej wielkiej dobroci. Jego wielki umysł ogarniał wszystko: to, co święte, i to, co świeckie; to, co dawne, i to, co nowe. Odwodził rozmówców od błędnych sądów, dyskutując na tematy, które sam poddawał, gdyż jego opinie zawsze były słuszne. Ci, którzy z nim rozmawiali, wychodzili zauroczeni i oświeceni" ${ }^{22}$.

Podobnego zdania o polskim monarsze był Bernard O'Connor, piszący, iż król lubi dysputy naukowe: „Uwielbiał przysłuchiwać się dyskusjom o filozofii i historii naturalnej. Sprytnie i ze szczególnym talentem otaczał się ludźmi wykształconymi, których rozmowy stanowiły dla niego rozrywkę" ${ }^{23}$.

Irlandzki lekarz nie pozostał gołosłowny i uraczył nas ciekawym opisem dyskusji medycznej z udziałem jego samego, spowiednika królewskiego, jezuity o. Maurycego

19 Ibidem, s. 199.

20 G.B. Fagiuoli, op. cit., s. 90.

21 Ph. Dupont, op. cit., s. 322.

22 Ibidem, s. 325. Zob. też K. Targosz, Jan III Sobieski mecenasem nauk i uczonych, Warszawa 2012, s. 41.

23 B. O'Connor, op. cit., s. 199-201. Pozytywny stosunek Irlandczyka do Jana III podkreśla T. Chynczewska-Hennel, Rzeczpospolita XVII wieku w oczach cudzoziemców, Warszawa 1994, s. 116-117. 
Karola Voty i biskupów poznańskiego Stanisława Witwickiego, płockiego Andrzeja Chryzostoma Załuskiego oraz wileńskiego Konstantego Kazimierza Brzostowskie$\mathrm{go}^{24}$. Tematem dyskusji było miejsce w ciele, w którym znajduje się dusza. Warto streścić przebieg owej debaty, gdyż okazała się ona starciem między zwolennikami dwóch odmiennych koncepcji filozoficznych - arystotelesowsko-tomistycznej i kartezjańskiej. Według pierwszej z nich dusza jest przede wszystkim odpowiedzialna za ożywianie ciała oraz kierowanie nim zgodnie $\mathrm{z}$ władzami przypisanymi duszy, gdzie myślenie jest jedną z władz, właściwą duszom ludzkim ${ }^{25}$. Kartezjusz z kolei mocno ograniczył funkcje duszy, redukując je w dużym stopniu jedynie do myślenia, co pociągnęło za sobą odmówienie istotom niemyślącym posiadania duszy. Stoczenie takiej dyskusji na dworze Jana III dowodzi, iż Wilanowowi bynajmniej nie pozostały obojętne wielkie problemy filozoficzne siedemnastowiecznej Europy.

Zabierając głos w wywołanej przez króla dyskusji, O’Connor w ślad za Kartezjuszem stwierdził, że dusza jest w mózgu, bo ten jedynie myśli. Kierujący się tomistyczną koncepcją duszy jako ożywiciela organizmu Vota uznał, że reszta ciała musiałaby być martwa, ponieważ dusza ożywia całe ciało i musi być wszędzie w nim. W odpowiedzi O'Connor wykazał się swą wiedzą medyczną i orzekł, że nie dusza ożywia, lecz krew, która krąży po całym ciele ${ }^{26}$. W tym momencie biskup poznański, który za młodu kształcił się na lekarza, zaczął skłaniać się ku zdaniu O’Connora, ale rozzłościło to jezuitę. Vota odwołał się do teologii i oznajmił, że takie poglądy są sprzeczne z nauką Kościoła i nie powinny być głoszone, bo jeśli dusza nie znajduje się w całym ciele i wszystkim nie kieruje, bylibyśmy podobni do zwierząt. O'Connor replikował, że i owszem, w działaniach ciała jesteśmy podobni do zwierząt, a dusza na to ma inne właściwości, by zajmować się racjonalnym myśleniem, a nie mechaniką ciała ${ }^{27}$. Król zagadnął z kolei, czym jest śmierć, skoro teologia scholastyczna uznaje, że jest to oddzielenie duszy od ciała. O'Connor stwierdził, że dusza w chwili śmierci oddziela się od ciała, ale ciało umiera najpierw z powodu ustania działania

24 Maurycy Karol Vota (1629-1715) - jezuita i spowiednik Jana III; Stanisław Witwicki (ok. 1630 1698) - biskup poznański; Andrzej Chryzostom Załuski (ok. 1650-1711) - biskup płocki; Konstanty Kazimierz Brzostowski (1644-1722) - biskup wileński. O dyspucie zob. K. Targ o sz, Jan III Sobieski..., s. 413-415.

25 Święty Tomasz z Akwinu, Traktat o człowieku (Summa teologii 1,75-89), thum. i oprac. S. Swieżawski, Kęty 2000, zwłaszcza kwestie 76 (o połączeniu duszy z ciałem) i 79 (o władzach umysłowych).

26 Irlandczyk odwołał się do odkrycia Williama Harveya o krążeniu krwi, opisanego w dziele De Motu Cordis, Frankfurt 1628. Dodajmy, że odkrycie to bynajmniej nie od razu i nie przez wszystkich zostało zaakceptowane.

27 Zauważmy w tym momencie, że o ile O’Connor trzyma się wiernie koncepcji kartezjańskiej, o tyle Vota nie wykorzystał w pełni filozofii tomistycznej, która nie odmawia wszak ludzkiej duszy władz niższych, odpowiedzialnych za funkcje życiowe, na których wyczerpują się z kolei władze dusz zwierzęcych $\mathrm{i}-\mathrm{w}$ jeszcze mniejszym stopniu - roślinnych. Rośliny i zwierzęta mają bowiem odpowiednio dusze wegetatywne i zmysłowe, podczas gdy ludzie wyróżniają się duszami rozumowymi, a każda z wyższych kategorii dusz zachowuje w sobie władze dusz niższych. 
jego organów wewnętrznych; wskutek tego dusza porzuca ciało ${ }^{28}$. Jan III podsumował to porównaniem duszy do organisty, który przestaje grać na zepsutych organach.

\section{JAN SOBIESKI JAKO WÓDZ I JEGO SŁAWA WOJENNA}

Spośród wszystkich umiejętności króla Jana III zdecydowanie najlepiej znane były w Europie jego talenty wojskowe. Swoich pochwał w tym zakresie nie szczędzili mu też obcy pamiętnikarze, jakkolwiek piszących w latach dziewięćdziesiątych czy już po śmierci króla wojownika musiały zastanawiać nikłe osiągnięcia militarne jego samego i Rzeczypospolitej po kampanii wiedeńskiej. Szukano też na to odpowiedzi, do których wrócimy w dalszym ciągu rozważań.

Bernard O'Connor, piszący swe dzieło już z perspektywy śmierci króla, a więc znający marazm na froncie polsko-tureckim, poświęcił wojnie z Osmanami kilka stron swego dzieła ${ }^{29}$. Ocenił Jana III jako bardzo dobrego wodza, który Turków tak przerażał, iż sami poprosili o pokój: „Turcy i Tatarzy stawali się powoli coraz potężniejsi. Pamiętali jednak o swych porażkach z ostatnich lat, a król Sobieski przerażał ich tak bardzo, że wydawało się, że jedyne, czego pragną, to zawarcie pokoju. W tym celu wielki wezyr, za pośrednictwem księcia Mołdawii, przygotował preliminaria traktatu, zatwierdzonego po zwycięskiej dla Polaków bitwie i kilku innych drobnych potyczkach, w których straty poniosły obie strony" ${ }^{\prime 30}$. Przytoczone tu stwierdzenie możemy odnieść najprawdopodobniej do turecko-tatarskich inicjatyw pokojowych z 1692 roku, przedsięwziętych po kampanii mołdawskiej Jana III z 1691 roku i obliczonych na wyprowadzenie Polski z szeregów Ligi Świętej ${ }^{31}$.

Pochwały Irlandczyka bledną jednak przy Dupontowskich peanach na cześć talentów militarnych króla. Francuski inżynier - skądinąd zawodowy żołnierz - wysławia wojenne czyny Jana III w całym swym dziele i - trzeba przyznać - zwykle

28 Odnotujmy, że zgodnie z filozofią tomistyczną (tu przywołaną jako scholastyczna), przyjmującą, iż dusza ożywia ciało (i jest to jej podstawowa funkcja), definicja śmierci jako oddzielenie się duszy od ciała jest prosta i racjonalna. Kartezjusz - a za nim O’Connor - ograniczając funkcje duszy do myślenia, nie mogli w sposób równie prosty wytłumaczyć związku między duszą a śmiercią. Siłą rzeczy pchnęło to O'Connora do utożsamienia śmierci z zanikiem funkcji życiowych ciała, postępującym bez związku $\mathrm{z}$ duszą, która w pewnym momencie jest niejako zmuszona do porzucenia ciała, zamierającego z przyczyn wyłącznie fizycznych. Stąd już niedaleko do stwierdzenia, że ciało odpowiada również za myślenie, a dusza w zasadzie do niczego nie jest potrzebna - tezy takie głosił w XVIII w. Julien Offray de La Mettrie, powołując się zresztą na obserwacje lekarskie (dzieło L'homme-machine, Leyden 1748; wyd. polskie: Człowiek - maszyna, thum. S. Rudniański, Warszawa 1953).

29 B. O'Connor, op. cit., s. 187-192.

30 Ibidem, s. 192.

31 Przywiezione do Warszawy w czerwcu 1692 r. przez posła tatarskiego propozycje pokojowe szły po myśli pary królewskiej i Ludwika XIV, toczącego wówczas wojnę z Ligą Augsburską, w której Habsburgowie grali pierwsze skrzypce. Niestety wbrew twierdzeniom O'Connora Turcy bynajmniej nie byli aż tak przerażeni, by odstąpić Polsce wszystkie żądane przez nią terytoria, i ostatecznie sprawa zawarcia odrębnego pokoju spełzła na niczym. Zob. Z. Wójcik, Jan Sobieski, Warszawa 1994, s. 476-477. 
ma po temu słuszne powody. Dla przykładu przytoczymy tylko jedną wypowiedź tego pamiętnikarza, której bardziej ogólny charakter dobrze odpowiada naszemu tematowi: „Nie było nigdy człowieka o większym geniuszu wojennym i umiejętności rozgrywania bitew. Miał marsową energię, która kazała mu ważyć się na wszystko i wszystko przedsiębrać. Doskonale umiał wykorzystać okazję i te krótkie momenty, od których zależy los bitew. Turcy odczuli to dobitnie pod Chocimiem i przy wielu innych okazjach. Najprostszego żołnierza ze swej armii potrafił natchnąć odwagą i męstwem. Wystarczyło na niego spojrzeć, gdy atakował z bronią w ręku. Mimo iż jego czyny były wielkie i chwalebne, nigdy się nimi nie przechwalał"'32.

Oszczędniejszy w tym względzie jest sekretarz nuncjusza, notujący o Janie III, iż „był dobrym żołnierzem”33. Z kolei de Mongrillon ocenił, że uzdolnienia wojskowe króla rozminęły się z możliwościami jego poddanych: „Miał bez wątpienia wielki talent do wojny i gdyby żył wśród ludów bardziej niż Polacy obeznanych w sztuce wojennej, dorównałby najsławniejszym dowódcom. Mimo że walczył tylko z Turkami, Tatarami i Moskalami, doskonale rozumiał naszą sztukę oblężniczą, nasze walki i nasz sposób prowadzenia wojny. Widać było wyraźnie, że nic nie uchodziło jego genialnej przenikliwości”"34. W stwierdzeniach Francuza daje się zauważyć poczucie dumy z potęgi militarnej jego ojczyzny, której armia po reformach Louvois i Vaubana była w stanie przeciwstawić się największym potęgom Europy. Widzimy też, że de Mongrillon dostrzegał różnicę między zachodnioeuropejskim systemem wojowania, zasadzającym się na oblężeniach i obronie twierdz oraz powolnym zdobywaniu terenu, a systemem wschodnim, któremu hołdował także Jan III, preferującym błyskawiczne kampanie i rozstrzygające bitwy.

Na ogół chwalił też króla Gaspard de Tende, wspominając między innymi świetne zwycięstwo pod Chocimiem, odniesione wespół z hetmanem wielkim litewskim Michałem Kazimierzem Pacem, oraz szybkie udanie się na kampanię wojenną tuż po elekcji w 1674 roku, ze szkodą interesów króla, jakie przyniosło - zdaniem pamiętnikarza - odłożenie koronacji ${ }^{35}$. Bez podania istotnych przyczyn niesłusznie obwinia jednak Sobieskiego o przerwanie kampanii chocimskiej, a także o kontynuowanie kampanii ukraińskiej zimą 1674/1675 roku - w relacji Francuza lepiej zgoła spisał się hetman Pac, który jesienią 1674 roku zdezerterował z wojskiem z Ukrainy, „by nie zginąć marnie $\mathrm{z}$ głodu i zmęczenia, tak jak się to stało z armią koronną" ${ }^{36}$. W efekcie król doprowadził do takiego zniszczenia armii koronnej, że rok później mógł przeciwstawić czternastotysięcznej ordzie jedynie trzy tysiące żołnierzy. A mimo to "odniósł zwycięstwo" pod Lesienicami, gdyż Tatarzy rzekomo nie ośmielili się zaatakować Polaków i zawrócili bez bitwy ${ }^{37}$.

32 Ph. Dupont, op. cit., s. 325.

33 G.B. Fagiuoli, op. cit., s. 90.

34 M. de Mongrillon, op. cit., s. 27.

35 G. de Tende, op. cit., s. 88-89 i 207-208.

36 Ibidem, s. 208.

37 Ibidem. Jest to przekaz całkowicie mylny. Bitwa pod Lesienicami była jednym z większych sukcesów Jana III w starciu z Tatarami (6 tys. Polaków wobec 12-15 tys. ordyńców). Zob. M. Wagner, Wojna polsko-turecka w latach 1672-1676, t. 2, Zabrze 2009, s. 176-187. 
Oczywiście z sukcesami na polu walki łączyła się zasłużona sława wojenna króla. Jej znaczenie podkreślał - już z perspektywy lat - M. de Mongrillon, z pewną przesadą pisząc: „Będąc prawdziwie wielkim dowódcą, budził wielki respekt swoich wrogów. Rzec można, nie schlebiając, że sam strach, jaki jego imię wzbudzało, spowodował odwrót Turków spod Wiednia, którzy omal nie opanowali miasta. Mogli bowiem zagrodzić przejście armii polskiej dziesięcioma tysiącami ludzi, opanowując głębokie wąwozy, przez które musiała ona przejść, aby do nich dotrzeć. Jednakże bliskość króla tak ich przeraziła, że nie pomyśleli o zajęciu tych wąwozów i pozostawili w ten sposób wolną drogę Polakom"38.

\section{LIGA ŚWIĘTA}

Udział Polski w Lidze Świętej, zawiązanej z udziałem papiestwa, Wenecji i Cesarstwa w 1684 roku, a uzupełnionej przez akces Moskwy w 1686 roku, był przedmiotem żywego zainteresowania obcych pamiętnikarzy. Sojusz ten z biegiem czasu stawał się coraz bardziej niewygodny dla Polski, krępując jej możliwości wojskowo-polityczne w Europie i kosztując wyrzeczenie się roszczeń do utraconych ziem na wschodzie (co było warunkiem sine qua non dołączenia się do przymierza Rosjan). Stawało się to coraz bardziej widoczne zwłaszcza wobec braku realnych sukcesów oręża polskiego - szczególnie bolesnych na tle zwycięstw austriackich. Wyprowadzenie Polski z Ligi było też jednym z głównych celów dyplomacji francuskiej, której przeciwstawiały się dwór wiedeński i Stolica Apostolska. Sam król wahał się, pragnąc przede wszystkim zdecydowanego zwycięstwa nad Osmanami. Urzeczywistnienia tego zamierzenia nie doczekał, ale też nie zdecydował się na separatystyczny pokój ze Stambułem, który - z czego też Jan III zdawał sobie sprawę - bynajmniej nie gwarantowałby trwałej pacyfikacji między Polską a Turcją.

Bernard O'Connor, pisząc o lidze przeciw Turkom i zauważając opieszałość Polaków w prowadzeniu wojny, uznał to za skutek niechęci do Niemców i sprzyjania przez króla Francuzom: „Funkcjonuje ona [Liga - przyp. D.M.] nadal, mimo że nie przynosi wielkich korzyści sojusznikom. Od oblężenia Wiednia Polacy czują bowiem niechęć do Niemców, których wybawili od tureckiej inwazji za to, że byli przez nich źle traktowani. Poza tym wydaje się, że król od kilku lat sprzyja Francji”’39.

$\mathrm{Z}$ kolei Gaspard de Tende widzi przyczynę niepowodzeń polskich raczej w złej organizacji armii, a zwłaszcza naczelnego dowództwa. Utyskuje na dożywotniość urzędu hetmańskiego i wskazuje wyraźnie na ograniczenia, jakie ma monarcha polski w doborze kandydatów na hetmana: „Zauważyłem również w Polsce inne negatywne zjawisko, które dotyczy urzędu hetmana armii. Otóż urząd ten jest dożywotni, a król nie może usunąć z niego osoby, która została mianowana; ponadto często musi przekazać ten urząd w ręce wielkiego pana, który nie ma pojęcia o sztuce wojennej.

\footnotetext{
38 M. de Mongrillon, op. cit., s. 30.

39 B. O'Connor, op. cit., s. 195.
} 
Nie należy się więc dziwić, że od czasu do czasu Polska doświadcza jakichś strat albo nie korzysta ze stosownych okazji osłabienia swych wrogów"40.

\section{ELEKCJA I SKĄPSTWO KRÓLA}

Elekcja Jana Sobieskiego na króla w maju 1674 roku dała okazję Dupontowi do wystawienia jeszcze jednej laurki swemu ulubieńcowi. Zdaniem Francuza nic innego jak tylko zalety Sobieskiego zapewniły mu koronę: „Rzeczpospolita potrzebowała nowego władcy i, wiedząc, co będzie dla niej korzystne, nie szukała po obcych dworach, mimo iż najsłynniejsi książęta zabiegali o koronę. Polacy dostrzegli w osobie Sobieskiego owo nagromadzenie zalet tak rzadkie u pojedynczego człowieka, które razem wzięte dają wielkiego króla. Został wybrany przy powszechnym aplauzie obywateli" ${ }^{41}$. Oczywiście odłożenie koronacji o prawie dwa lata (do lutego 1676 r.) było według tegoż pamiętnikarza poświęceniem się Jana III dobru publicznemu zamiast własnemu ${ }^{42}$.

Opis ten miał niewiele wspólnego z rzeczywistością. Jakkolwiek entuzjazm szlachty dla zwycięzcy spod Chocimia był wiosną 1674 roku autentyczny, bynajmniej nie on jeden wprowadził hetmana wielkiego koronnego na tron. Jan Sobieski umiejętnie rozegrał partię polityczną, wykorzystując między innymi swoje uprawnienia z tytułu jednoczesnego sprawowania urzędu marszałka wielkiego koronnego do sprowadzenia wojska w pobliże Warszawy i wywarcia presji na elektorów, co nie było do końca zgodne $\mathrm{z}$ duchem prawa ${ }^{43}$. Podobnie odłożenie koronacji służyło przede wszystkim utrzymaniu przez króla elekta swych wpływów w armii, której komendę musiałby oddać nowo mianowanemu hetmanowi wielkiemu koronnemu (nominacja musiała zaś nastąpić po koronacji króla hetmana) ${ }^{44}$. Co ciekawe, mówi o tym wprost O'Connor, zaznaczając, iż szlachta zaakceptowała decyzję króla o odłożeniu koronacji dla zachowania uprawnień urzędu hetmańskiego ${ }^{45}$. De Tende z kolei nie rozumie przyczyn odłożenia koronacji i dziwi się im, skoro dawała ona królowi realne uprawnienia rozdawnicze, a więc umożliwiała zyskiwanie zwolenników ${ }^{46}$. Ten sam autor wspomina też o ,sporze”, a wręcz bijatyce wśród Litwinów, do jakiej doszło tuż przed elekcją, a którą Sobieski faktycznie wywołał, a następnie zręcznie wykorzystał

40 G. de Tende, op. cit., s. 223.

41 Ph. Dupont, op. cit., s. 39.

42 Ibidem.

43 K. Wiśniewski, Jan Sobieski jako marszałek wielki koronny [w:] Marszałek i hetman koronny Jan Sobieski, red. D. Milewski, Warszawa 2014, s. 31-35; idem, Urzad marszalkowski koronny w bezkrólewiach XVII-XVIII wieku (1632-1736), Warszawa 2015, s. 104-105.

44 Z. Hundert, Pozycja Jana III w wojsku koronnym w latach 1674-1683. Utrzymanie czy też utrata wplywów wypracowanych $w$ czasie sprawowania godności hetmańskiej? [w:] Król Jan III Sobieski i Rzeczpospolita w latach 1674-1683, red. D. Milewski, Warszawa 2016, s. 126-127.

45 B. O'Connor, op. cit., s. 186.

46 G. de Tende, op. cit., s. 207. 
do szantażu politycznego - jako marszałek mógł sądzić winnych, ale zrezygnował $\mathrm{z}$ tego za cenę wycofania sprzeciwu litewskiego wobec kandydatury „Piasta”. Francuz zauważa, że sprawa ta „,w niemały sposób przyczyniła się do jego [Sobieskiego] wyboru", ale przemilcza istotną rolę, jaką odegrał tu przyszły monarcha ${ }^{47}$.

Dużo bliższy prawdy w opisie okoliczności towarzyszących obiorowi Jana III jest zatem Giovanni Fagiuoli, który pisał o królu: „Wywodzi się z Rusi, i chociaż Ruś jest częścią Królestwa Polskiego, mimo to został wybrany na króla, co było sprzeczne z konstytucjami polskimi, które nakazują, aby król był obcokrajowcem, ale on, będąc zwierzchnikiem zbrojnym i mając pieniędzy w bród, które bardzo lubi i których jest wielkim przyjacielem, mocą pierwszego i potęgą drugiego wsadził sobie koronę na głowę" ${ }^{48}$. W relacji Włocha znalazła się informacja o wykluczeniu przez prawo Polaka („Piasta”) spośród kandydatów do korony. Było to odbiciem postulatów litewskiego stronnictwa pacowskiego, zgłoszonych na sejmie konwokacyjnym w 1674 roku i wymierzonych milcząco właśnie w hetmana wielkiego koronnego, politycznego przeciwnika kanclerza wielkiego litewskiego Krzysztofa Zygmunta Paca i jego brata, hetmana wielkiego litewskiego Michała Kazimierza Paca. Trzeba jednak podkreślić, iż postulatu tego nie zrealizowano wskutek oporu między innymi ówczesnego podkanclerzego koronnego Andrzeja Olszowskiego, broniącego dobrej pamięci zmarłego króla-Piasta Michała Korybuta Wiśniowieckiego. Pomimo częściowego sukcesu Litwinów na sejmie konwokacyjnym sprawa ekskluzji Piasta upadła 30 kwietnia na sejmie elekcyjnym ${ }^{49}$. Jan Sobieski, kandydując do korony, nie złamał zatem prawa.

Skoro jesteśmy już przy królu Michale, warto zaznaczyć, że Philippe Dupont - nie bacząc na udział Jana Sobieskiego w planach detronizacji króla - zapisał na konto swego ulubieńca, iż w 1672 roku odstąpił on od zemsty na niewdzięcznym królu, który usiłował go zabić (nawiązanie do planów konfederatów gołąbskich, zmierzających do osądzenia malkontentów, do których zaliczał się i hetman wielki koronny $)^{50}$. Niewdzięczność królewska była zaś tym widoczniejsza, im bardziej podkreślał pamiętnikarz bezinteresowność hetmana, który rok wcześniej, podejmując kampanię na Ukrainie, ,przepełniony miłością, jaką zawsze żywił dla ojczyzny, starał się uchronić ją przed przykrymi skutkami brutalnych planów kozackiego hetmana [Piotra Doroszenka]"

Jedną z większych wad Jana III, widocznych zwłaszcza pod koniec życia, było skąpstwo. Bernard O’Connor wspomniał co prawda o hojności króla, ale odniósł ją do początków panowania, kiedy to elekt obiecał wystawić tysięczny oddział piechoty $^{52}$. Podsumowując jego rządy, nie wahał się pisać o Janie III jako o sknerze, który

47 Ibidem, s. 154.

48 G.B. Fagiuoli, op. cit., s. 90.

49 Z. Wójcik, Jan Sobieski, s. 216-217; T. Korzon, Dola i niedola Jana Sobieskiego, t. 3, Kraków 1898, s. 448-449, 481-484; K. Bobiatyński, Michat Kazimierz Pac - wojewoda wileński, hetman wielki koronny. Działalność polityczno-wojskowa, Warszawa 2008, s. 304-306; K. Wiśniewski, Urząd marszatkowski..., s. 96-99.

50 Ph. Dupont, op. cit., s. 66.

51 Ibidem, s. 56.

52 B. O'Connor, op. cit., s. 186. 
wolał gromadzić majątek, niż wydawać pieniądze na cele wojenne: „Wiadomo na pewno, że pokochał pieniądze. Sam słyszałem, jak Polacy mówili, że był najbardziej chciwym i najbogatszym księciem spośród wszystkich, którzy nimi rządzili. Wyliczyli, że każdego roku przez 22 lata rządów odkładał sto tysięcy funtów szterlingów, które powinien był przeznaczać na wydatki związane z prowadzeniem wojen, co czynili wszyscy jego poprzednicy. Co więcej, niektórzy szlachcice mówili mi, że gdyby jego syn Jakub został następcą, musiałby wydać większą część tego skarbu na spłatę ośmioletnich zobowiązań względem wojska" ${ }^{33}$.

Wymieniał zatem Irlandczyk wielkie bogactwa króla, notując, iż miał on ponad 100 tysięcy funtów szterlingów rocznego dochodu, odkładanych w bankach Gdańska, Hamburga i Amsterdamu. Reszta wpływów była powierzona Żydom, bardzo licznym w Polsce, by obracali pieniędzmi króla. Jan III kupił wielkie posiadłości w Polsce, choć jest to sprzeczne z prawem (tu niewątpliwie nawiązanie do Wilanowa). Przewidywał też O’Connor, że jeśli młodzi Sobiescy: Jakub, Aleksander i Konstanty dobrze będą zarządzać majątkiem ojca, będą mieć każdy ponad 50 tysięcy funtów szterlingów rocznie ${ }^{54}$.

O'Connorowi wtórował Giovanni Fagiuoli, który powołując się na opinię publiczną, ocenił, iż król „,nagromadził pieniędzy”, a w jednym ze swych zamków „odłożył około 15 milionów ungarów [dukatów węgierskich - przyp. D.M.] w gotówce, inni jeszcze twierdzą, że 17 milionów oprócz mnóstwa klejnotów o nieoszacowanej wartości, wszystko z łupów zarówno w Chocimiu, jak i w Wiedniu, kiedy przybył osobiście $\mathrm{z}$ trzonem armii całego Królestwa na odsiecz temu miastu oblężonemu przez Turka w roku 1683"55.

Kropkę nad „,i” stawia M. de Mongrillon, który skąpstwu polskiego monarchy przypisuje kłopoty wojenne Rzeczypospolitej i nikłe wyniki walki z Osmanami. Co więcej, pisząc już w dniach bezkrólewia po śmierci Jana III, ocenił, że ta sama wada przeszkodziła królowi zadbać o odpowiednie wychowanie swoich synów i utorowanie jednemu z nich drogi do tronu polskiego: „Władca ten posiadał wszelkie zadatki na największego króla świata, ale skąpstwo psuło mu wszystko i uniemożliwiało wykorzystanie swoich wielkich zalet. Odznaczał się wielkim umysłem, był bardzo miły, posiadał dużo wiedzy, stałości, delikatności, roztropności i skrytości. Nie będę mówił o jego znaczeniu, gdyż narobiło ono dość hałasu w całej Europie. Skąpstwo, które go opanowało, stało się hamulcem wszystkich jego poczynań. Jeśli, co szczególnie w ostatnich latach swojego życia, prowadził wojnę ślamazarnie lub nonszalancko, to dlatego, że energiczniejsza wojna wymagałaby większych wydatków. Skąpstwo i zobojętnienie przeszkadzało mu myśleć o zachowaniu korony w swojej rodzinie i zawsze powodowało zaniedbania w edukacji książąt, jego dzieci, w otoczeniu których nigdy nie było zdolnych ludzi" ${ }^{56}$. Dalej też Francuz powtórzył swoje zdanie, że gdyby nie skąpstwo i zobojętnienie króla, miałby on większy wpływ na przebieg

53 Ibidem, s. 195.

54 Ibidem, s. 202.

55 G.B. Fagiuoli, op. cit., s. 90.

56 M. de Mongrillon, op. cit., s. 26-27. O edukacji młodych Sobieskich zob. A. Skrzypietz, Królewscy synowie - Jakub, Aleksander i Konstanty Sobiescy, Katowice 2011, s. 47-66. 
wojny: „[Jan III] mógłby, gdyby zechciał, stać się arbitrem Europy w ostatniej wojnie, lecz skąpstwo i zobojętnienie ogarnęło go zbyt mocno"57.

Jak widać, oceny cudzoziemców są w dużym stopniu uzależnione od niechętnej królowi propagandy opozycyjnej i pogłosek przypisujących monarsze zobojętnienie na sprawy wojskowe. Tymczasem wiemy skądinąd, że do końca życia król interesował się wojną i stanem wojska i niejednokrotnie dokładał środków z własnej szkatuły na zaspokojenie najpilniejszych potrzeb armii. Niemniej jesteśmy też świadkami wciąż żywego przeświadczenia Polaków - bez wątpienia znużonych przeciągającą się wojną - iż obowiązkiem monarchy jest utrzymanie wojska. Myśl ta, która swego czasu legła u podstaw ruchu egzekucyjnego i pozwoliła na zorganizowanie wojska kwarcianego, w dobie Jana III była już całkowicie anachroniczna, a koszty utrzymania rozbudowanej armii musiało wziąć na siebie społeczeństwo. Wobec chronicznego niedochodzenia sejmów w drugiej połowie rządów Jana III nie można było zapewnić regularnego finansowania wojska, a zatem i uzyskać pozytywnych efektów w prowadzonej wojnie. Wygodniej wszakże było szlachcie obciążyć winą króla, niż przyznać się do odpowiedzialności za stan finansów państwa.

Co do oceny skąpstwa Jana III, to jest ona częściowo uzasadniona. Król pod koniec życia stał się rzeczywiście pazerny i gromadził bogactwa, które ostatecznie zamiast zapewnić sukcesję w rodzie Sobieskich, przyczyniły się do ich politycznej katastrofy (znany i gorszący spór Jakuba Sobieskiego z matką o schedę po Janie III) ${ }^{58}$.

\section{RYSOPIS KRÓLA}

Na zakończenie wypada nam pochylić się nad rysopisem monarchy, tak bardzo polskiego w swych obyczajach i stroju, a tym samym tak obcego cudzoziemcom przyzwyczajonym do mody francuskiej. Philippe Dupont kreśli jak zwykle pozytywny obraz króla: „Wielki ten władca miał twarz doskonale owalną, fizjonomię szlachetną i dumną, oczy tak żywe i płomienne, że trudno było wytrzymać ich spojrzenie. Nos miał rzymski, głos bardzo przyjemny. Pod koniec życia mocno utył, ale będąc ponadprzeciętnego wzrostu, miał wskutek tuszy tylko więcej majestatu w postawie, zwłaszcza gdy ubrany był po polsku" 59 .

Podobnie wypowiada się o Janie III Giovanni Fagiuoli, który poznał króla, gdy ten przekroczył sześćdziesiąty rok życia: ,jest wysokiego wzrostu, o rudo-siwych włosach, bardzo gruby i wielki proporcjonalnie do wzrostu, jest przystojny i ma bardzo bystre spojrzenie; kiedy był młodzieńcem i przez dłuższy czas mieszkał we Francji, był powszechnie nazywany pięknym Polakiem" ${ }^{60}$.

57 M. de Mongrillon, op. cit., s. 30 .

58 Z. Wójcik, Jan Sobieski, s. 389-390.

59 Ph. Dupont, op. cit., s. 325.

60 G.B. Fagiuoli, op. cit., s. 90. Dodajmy, że Włoch błędnie ocenił wówczas wiek króla na „około 64 lata". 
Widzimy zatem, że pamiętnikarze na ogół chwalą wzrost i królewską posturę Jana III, przy czym powiększająca się z każdym rokiem otyłość króla nie była dla nich niczym złym. Nie dziwi nas to, zważywszy na upodobania estetyczne epoki, słynącej z rubensowskich kształtów. Może warte odnotowania jest, iż utrzymujący się w Polsce w XVIII wieku sarmatyzm pozwolił Jędrzejowi Kitowiczowi na wystawienie podobnie pochlebnej opinii pod adresem otyłego Augusta III Wettyna ${ }^{61}$. W tym samym czasie we Francji obżarstwo i idąca w ślad za nim otyłość Ludwika XVI będą już budziły zgorszenie otoczenia ${ }^{62}$.

\section{OGÓLNA OCENA KRÓLA}

W ogólnej ocenie władcy polskiego najwięcej superlatywów znajdziemy u Philippe'a Duponta. Spośród wielu generalnych pochwał pod adresem króla, rozproszonych po całym tekście Dupontowskich pamiętników, przytoczmy dla przykładu jedną: „Wszystko było wielkie w tym księciu, którego czyny wojenne zamierzam opisać. Był obdarzony bezprzykładną odwagą. Okazał się równie świetnym żołnierzem, co zręcznym wodzem, wszechstronnie wykształconym. O wszystkim wypowiadał się w sposób znakomity i z wiedzą. Oczarowywał każdego, kto miał okazję z nim rozmawiać" 63 .

Podobną ocenę wystawił sarmackiemu królowi krytyczny skądinąd Fagiuoli, który pisząc z perspektywy trudnych lat końca XVII wieku, wyraził interesującą opinię na temat przemijania sławy królewskiej po odsieczy wiedeńskiej: „gdyby zmarł po tym ostatnim zwycięstwie, umarłby jako najsławniejszy Król katolicki (czy prawowierny, jak sam o sobie mówił), jaki kiedykolwiek żył w Europie" ${ }^{64}$. Jak wiadomo, zdanie to podchwycił znany publicysta Paweł Jasienica, rozważając w tym kontekście hipotetyczne szanse elekcyjne Jakuba Sobieskiego i uniknięcie przez Rzeczpospolitą rządów nielubianego przez Jasienicę Augusta II Mocnego ${ }^{65}$.

Przyglądając się ogólnej ocenie życia i poczynań polskiego monarchy wystawionej mu przez cudzoziemskich pamiętnikarzy, możemy zgodzić się, iż była ona pozytywna. Swoją rolę odegrała tu bez wątpienia sława zwycięstwa wiedeńskiego, która odbiła się w Europie szerszym echem niż kładące się cieniem na ostatnie lata panowania kłopoty wewnętrzne i ataki opozycji. Trzeba jednak uczciwie przyznać, że cudzoziemcy dostrzegali niewesoły schyłek rządów Jana III i potrafili go włączyć do swojej oceny władcy.

${ }^{61}$ J. Kitowicz, Pamiętniki, czyli Historia polska, oprac. P. Matuszewska, Warszawa 2005, s. $111-112$.

${ }^{62}$ Lakomstwem wnuka gorszył się już Ludwik XV, obserwujący zachowanie swego następcy w czasie uczty weselnej po małżeństwie Ludwika z Marią Antoniną w 1770 r. - zob. T. Serwatka, Poczet władców Francji, Londyn 1996, s. 89, 96.

$63 \mathrm{Ph}$. Dupont, op. cit., s. 31.

${ }^{64}$ G.B. Fagiuoli, op. cit., s. 90.

65 P. Jasienica, Rzeczpospolita Obojga Narodów, t. 2: Calamitatis regnum, Warszawa 1992, s. 383. 


\section{BIBLIOGRAFIA}

\section{Źródła}

[Dupont Ph.], Mémoires pour servir à l'histoire de la vie et des actions de Jean Sobieski III, du nom roi de Pologne par Philippe Dupont attaché à ce prince en qualité d'ingénieur en chef de l'artillerie, publiés d'après manuscrit par I. Janicki, Varsovie 1885.

Dupont Ph., Pamiętniki historyi życia i czynów Jana III Sobieskiego, tłum. B. Spieralska, oprac. D. Milewski, Warszawa 2011.

Fagiuoli G.B., Diariusz podróży do Polski (1690-1691), oprac. M.E. Trzeciak, Warszawa 2017.

Fagiuoli J.Ch., Djariusz podróży do Polski wyjęty z pamiętników Jana Chrzciciela Faggiuoli, wyd. W. Kulczycki, „Czas. Dodatek miesięczny” 1858, R. 3, t. 11.

Kitowicz J., Pamiętniki, czyli Historia polska, oprac. P. Matuszewska, Warszawa 2005.

La Mettrie J.O., Człowiek - maszyna, tłum. S. Rudniański, Warszawa 1953.

Mongrillon M. de, Pamiętnik, oprac. Ł. Częścik, Wrocław 1982.

O'Connor B., Historia Polski, tłum. W. Duży, T. Falkowski, P. Hanczewski, K. Pękacka-Falkowska, red. nauk. P. Hanczewski, Warszawa 2012.

Tende G. de, Relacja historyczna o Polsce, tłum. i red. nauk. T. Falkowski, wprowadzenie M. Forycki, Warszawa 2013.

[Tende G. de], Le Sieur de Hauteville, Relation historique de la Pologne contenant le pouvoir de ses Rois, leur élection, \& leur Couronnement, les privileges de la Noblesse, la Religion, la Justice, les moeurs \& les inclinations des Polonois; avec plusieurs actions remarquables, Paris 1686.

Tomasz z Akwinu, święty, Traktat o człowieku (Summa teologii 1,75-89), thum. i oprac. S. Swieżawski, Kęty 2000.

\section{Opracowania}

Bobiatyński K., Michał Kazimierz Pac-wojewoda wileński, hetman wielki koronny. Działalność polityczno-wojskowa, Warszawa 2008.

Chynczewska-Hennel T., Rzeczpospolita XVII wieku w oczach cudzoziemców, Warszawa 1994.

Czarniecka A., „Nikt nie stucha mnie za życia...”. Jan III Sobieski w walce z opozycyjna propaganda (1684-1696), Warszawa 2009.

Hundert Z., Pozycja Jana III $w$ wojsku koronnym w latach 1674-1683. Utrzymanie czy też utrata wplywów wypracowanych w czasie sprawowania godności hetmańskiej? [w:] Król Jan III Sobieski i Rzeczpospolita w latach 1674-1683, red. D. Milewski, Warszawa 2016.

Jasienica P., Rzeczpospolita Obojga Narodów, t. 2: Calamitatis regnum, Warszawa 1992.

Komaszyński M., Filip Dupont - dworzanin doskonały [w:] Studia z dziejów epoki Jana III Sobieskiego, red. K. Matwijowski, Wrocław 1984.

Korzon T., Dola i niedola Jana Sobieskiego, t. 3, Kraków 1898.

Lynn J.A., Wojny Ludwika XIV 1667-1714, tłum. W. Brillowski, Oświęcim 2015. 
Milewski D., „Pamiętniki...” Philippe’a Duponta, czyli historia zwycięstw i stawy Jana Sobieskiego [w:] Z dziejów staropolskiego pamiętnikarstwa. Przekroje i zbliżenia, red. P. Borek, Kraków 2012.

Pietrzak J., Księżna dobrodziejka Katarzyna z Sobieskich Radziwiłtowa (1634-1694), Warszawa 2016.

Piwarski K., Dupont Filip [w:] Polski słownik biograficzny, t. VI, Kraków 1948.

Sajkowski A., W stronę Wiednia. Dole i niedole wojenne $w$ świetle listów i pamiętników, Poznań 1984.

Serwatka T., Poczet władców Francji, Londyn 1996.

Skrzypietz A., Królewscy synowie - Jakub, Aleksander i Konstanty Sobiescy, Katowice 2011.

Szpilczyński S., Wójcik Z., O’Connor Bernard (ok. 1666-1698) [w:] Polski słownik biograficzny, t. XXIII, Wrocław-Warszawa-Kraków-Gdańsk 1978.

Targosz K., Jan III Sobieski mecenasem nauk i uczonych, Warszawa 2012.

Targosz K., Uczony dwór Ludwiki Marii Gonzagi (1646-1667). Z dziejów polsko-francuskich stosunków naukowych, Warszawa 2015.

Wagner M., Wojna polsko-turecka w latach 1672-1676, t. 2, Zabrze 2009.

Wiśniewski K., Jan Sobieski jako marszałek wielki koronny [w:] Marszałek i hetman koronny Jan Sobieski, red. D. Milewski, Warszawa 2014.

Wiśniewski K., Urząd marszałkowski koronny w bezkrólewiach XVII-XVIII wieku (16321736), Warszawa 2015.

Wójcik Z., Jan Sobieski, Warszawa 1994.

Wójcik Z., Polska w oczach irlandzkiego lekarza-humanisty Bernarda Connora [w:] Biedni i bogaci. Studia z dziejów społeczeństwa i kultury ofiarowane Bronisławowi Geremkowi w sześćdziesiąta rocznicę urodzin, red. M. Aymard i in., Warszawa 1992. 